\title{
HYDROGEOLOGIC FRAMEWORK OF THE GARDUNHA MOUNTAIN: NORTHEAST AREA - CENTRAL PORTUGAL
}

The present paper describes the hydrochemical evolution of mineral groundwater in the northeast area of Gardunha mountain (centre region of Portugal) which is formed by low permeability igneous rocks. For this study were considered 50 water samples and analyzed the values of major ions. The methodology used consisted in the use of Piper diagrams that had allowed to identify the water chemistry and in the application of statistical techniques of multivariate analysis, including factor analysis. The results guided to sodium-bicarbonate water type, with very low mineralization, designated by fresh water in relation to total solids and soft in relation to hardness. When using the factor analysis, 4 factors were considered, which explain and identify the origin of the presence of ions and their geochemical processes.

\section{Introduction}

The groundwater is a natural resource essential to the life and the integrity of the ecosystems, representing more than $95 \%$ of the Earth fresh water reservoirs that can be explored. Most of the agricultural and industrial activities depend on groundwater, which is also fundamental for the public supply, once more than a half of the world population depend on this groundwater. In Europe, the groundwater supplies approximately $65 \%$ of the water used for human consumption [1].

Being a natural resource this water has had a decisive role in the flourishing of civilizations and constitutes nowadays a privileged source of most public and private supplies [2].

The quality of the groundwater is given by the dissolution of the minerals present at the rocks that constitute the aquifers and the percolation through them. Nevertheless, other factors may influence its quality, such as the composition of the recharge water, the residence time, the interaction water-physical environment, the climate and even the pollution caused by human activities.

In the whole world the aquifers are at risk of being contaminated because of the urbanization, the industrial development, the agricultural activities and the mine extractive industries.

In Portugal, having already some knowledge in the hydrogeological area, it is possible to identify for some hydrogeological units the existence of potential reservoirs that should be better acquainted and evaluated, once, if they were well used, they could become "emergency structures", providing help in crisis situations.

However, among all these needs what emerges as being particularly relevant is the supplying of water for human purposes, which demands high quality standards, either in the water supply or in the service provided to consumers.

With this present study we intend to contribute to the hydrogeological and hydrochemical knowledge of the northeast area of Gardunha mountain (centre region of Portugal).

\section{Study area}

The Gardunha mountain is a structural unit perfectly individualized which belongs to the Iberian Massif, and it is limited for several depressions in which stands out on the SE the highest area of the hydrographic basin of the Riverside of Alpreade, where it is located Castelo Novo (Fig. 1). This mountain is characterized physically as an area with a rugged landscape, it presents to the West old formations composed by metamorphic shale and to the East granitic igneous lands, culminating to the elevation $1227 \mathrm{~m}$.

The captations in study are located all in hercynian granitic orogeny of varied textures. Locally they form two different granitic series, although, to the genetic-tectonic and chemical-mineralogical point of view they seem to make a junction in an only branch, within the orographic hercynian: (1) granites with biotite-oligo-

\footnotetext{
* Eric Mendes, Paulo E. M. Carvalho, Luís M. Ferreira Gomes

Universidade da Beira Interior, Departamento de Engenharia Civil e Arquitectura, 6201-001 Covilhã, Portugal, E-mail: emendes@ubi.pt
} 


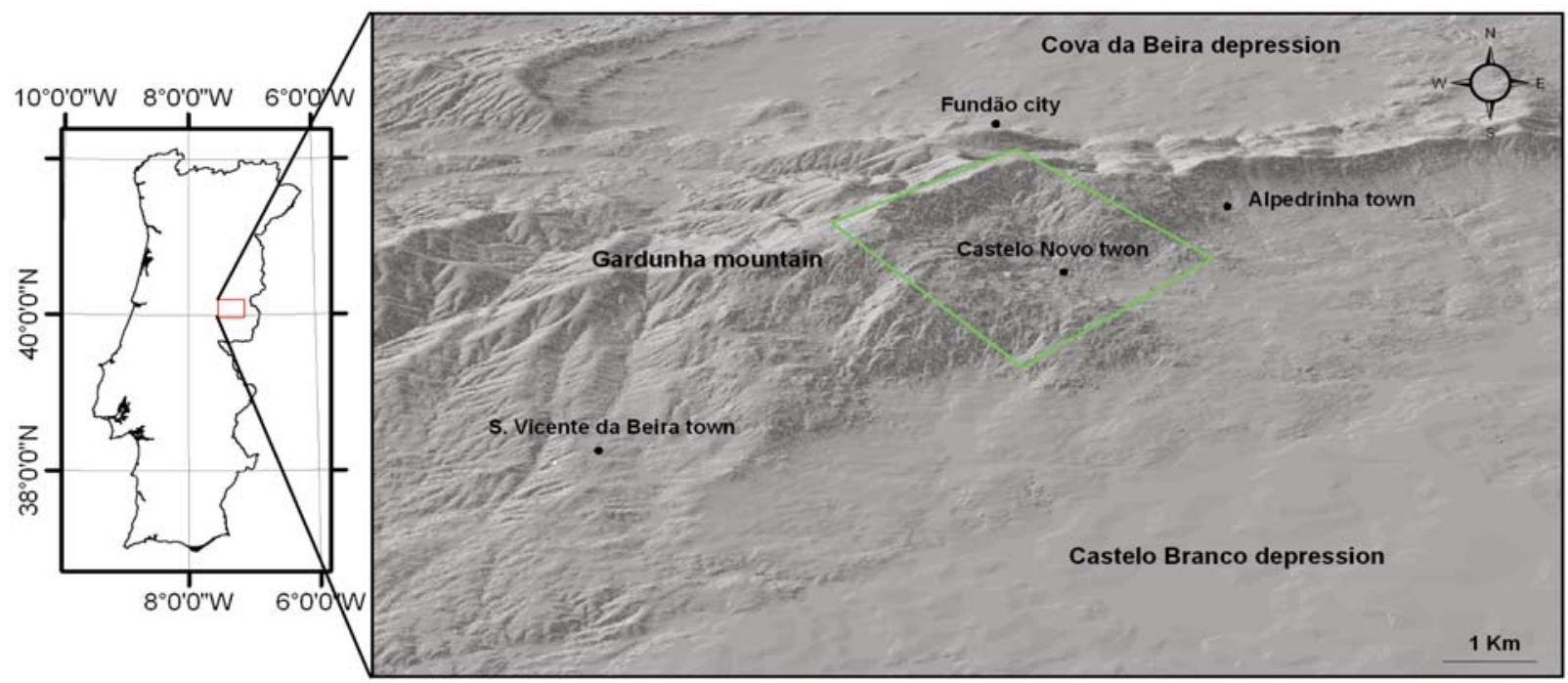

Fig.1 Location map of the study. The green line delimited the study area.

clase mega crystals; (2) post tectonic granites bounded in massifs, usually biotitic and frequently with mega crystals.

As for the constitution of mineralogical essentials they have quartz, oligoclase, microcline, microcline-partite, albite-oligoclase and biotite. As secondary elements there is muscovite, apatite, zircon, turmaline, magnetite, ilmenite, pyrite, fluorite [3].

The granitic rocks and the surrounding grounds are affected by tectonic hercynian and late-hercynian actions that lead to metamorphism, folding and fracture. The fracture is noticed by the presence of fault lines widely spread all over the area, situated mainly NNESSW and NE-SW, where sometimes one can find pegmatítics, aplitepegmatítics and hydrothermal veins of quartz [3].

The localization of the springs is conditioned by the presence of permeable conducts, due not only to this tectonic fracture but also because of the piezometric and topographical surface. Some of these factors were reactivated in the Quaternary, occurring at the same time the thermal springs with the presence of the active faults [4].

From the climatic elements available to the characterization of the area of study, was used the information related to the precipitation registered in the weather centre of Castelo Novo 13M/03G [5]. For the monthly rating of the hydrological balance, it was used a methodology suggested by Thornthwaite and Mather [6] and through the results one can notice the emergency of a dry period and a damp period, being the first due to the hydraulic shortage, that goes from June until September, having its peak in August, and the second, the damp period, is due to the hydraulic superavit, that goes from October until May, having the greatest amount of water in January.

In terms of hydrogeological units, as a whole, it is accepted as valid that it corresponds to a aquifer of the phreatic fissural type, with hydraulic conductivity that varies between 0.008 and $2.38 \mathrm{~m} / \mathrm{d}$ and transmissivity values that vary between 0.28 e $54.8 \mathrm{~m}^{2} / \mathrm{d}$.

The groundwater flow is not very deep, as proved especially by the low mineralization of the water, considering that it is an aquifer of common superficial water, containing mainly infiltration waters and local flow, lasting for short periods of time.

The speed of the flow is generally high, given the type of permeability per fracture; the maintenance of the streams, even during the dry period, is probably due to the capacity of regularization of the alteration areas that covers some of the rechargeable areas. During the dry periods above all the permeability, because of the porosity of the alteration areas, plays a very important role, although all the hydraulic action is conditioned by the flowing through the fractures.

A hydrogeological conceptual model for this region is showed in Fig. 2, showing that the infiltrated water tends to emerge in places not very distant, nevertheless notice that part of the groundwater flow can evolve to great depth along the large faults, recharging deep aquifers.

\section{Analytical Methods}

In order to study the groundwater quality, 50 groundwater samples have been collected for analysis of major and trace elements. $\mathrm{pH}$ and electrical conductivity $(\mu \mathrm{S} / \mathrm{cm})$ were measured at the sampling site by the use of a multi-parameter analyzer, SCHOTT - PH/LH 12. The following methods were applied for chemical analyses performed at the Laboratory of Analyses of the Technical Institute (Instituto Superior Técnico): molecular absorption spectrometry for $\mathrm{SiO}_{2}{ }^{2+}$; atomic absorption spectrometry for $\mathrm{Pb}$, $\mathrm{Cu}, \mathrm{Cr}, \mathrm{Sr}, \mathrm{Rb}$; ion chromatography for $\mathrm{Cl}^{-}, \mathrm{HCO}_{3}^{-}, \mathrm{NO}_{3}{ }^{-}$, $\mathrm{SO}_{4}{ }^{2-}, \mathrm{Ca}^{2+}, \mathrm{Mg}^{+}, \mathrm{K}^{+}, \mathrm{Na}^{+}$. 


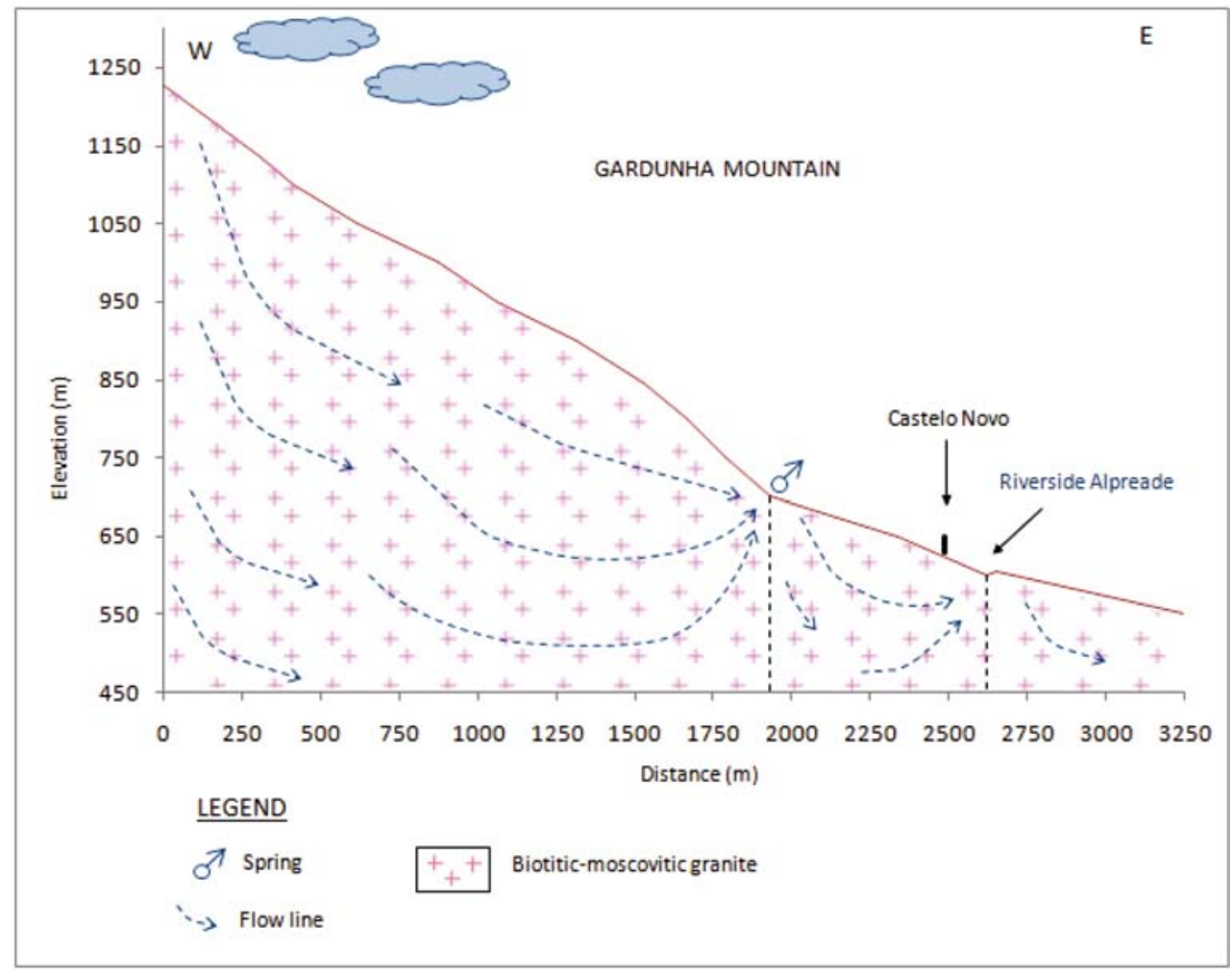

Fig.2 Hydrogeological conceptual model in the studied area

\section{Results and discussion}

\section{Hydrochemistry}

According to the analytical data (Table 1), in the groundwater investigated, the average $\mathrm{pH}$ is about 5.76 and the electrical conductivity (EC) ranges from $20-30 \mu \mathrm{S} / \mathrm{cm}$. The total dissolved solids (TDS) vary from 24.2 to $41.3 \mathrm{mg} / \mathrm{l}$, the average value being of $31.6 \mathrm{mg} / \mathrm{l}$, is fresh water based on Freeze and Cherry (1979) classification.

The dominant ions in solution are $\mathrm{HCO}_{3}{ }^{-}$and $\mathrm{Na}^{+}$, which represent on average respectively 61 and $71 \%$ of the total content of anions and cations.

The $\mathrm{Cl}^{-}>\mathrm{SO}_{4}{ }^{2-}>\mathrm{NO}_{3}{ }^{-}$anions are secondary in importance, representing on average $39 \%$ of all anions. Among the cations $\mathrm{Ca}^{2+}>\mathrm{K}^{+}>\mathrm{Mg}^{2+}$ are less abundant, they represent on average $29 \%$ of all the cations. The concentration of $\mathrm{SiO}_{2}{ }^{2+}$ varies between 9.5 and $18.4 \mathrm{mg} / \mathrm{l}$. These contents of dissolved silica can be related to the hydrolysis of the silicate minerals present in the igneous rocks. This process could also contribute to the rise of the contents of $\mathrm{HCO}_{3}{ }^{-}$and alkali metals $\left(\mathrm{Na}^{+}\right.$and $\left.\mathrm{K}^{+}\right)$or alkali muddy $\left(\mathrm{Ca}^{2+}\right.$ and $\left.\mathrm{Mg}^{2+}\right)$.

According to the physical-chemistry composition presented, this groundwater is classified as bicarbonate-sodium type (Fig. 3), hypo-saline with acid and silicate reaction.
Summary statistics of the geochemical analysis

Table 1

\begin{tabular}{|c|c|c|c|c|c|c|}
\hline $\begin{array}{c}\text { Water } \\
\text { quality } \\
\text { parame- } \\
\text { ters }\end{array}$ & Units & Min. & Max. & Average & Median & $\begin{array}{c}\text { Guideline } \\
\text { value } \\
\text { WHO } \\
(2004)\end{array}$ \\
\hline $\mathrm{pH}$ & - & 5.34 & 6.19 & 5.76 & 5.77 & $6.5-9.5$ \\
\hline $\mathrm{EC}$ & $\mu \mathrm{S} / \mathrm{cm}$ & 20 & 30 & 24.1 & 23 & - \\
\hline $\mathrm{TDS}$ & $\mathrm{mg} / 1$ & 24.2 & 41.3 & 31.6 & 30.5 & 1200 \\
\hline $\mathrm{SiO}_{2}{ }^{2+}$ & $\mathrm{mg} / 1$ & 9.5 & 18.4 & 13.9 & 13.5 & - \\
\hline $\mathrm{Cl}^{-}$ & $\mathrm{mg} / 1$ & 1.9 & 2.6 & 2.14 & 2.1 & 250 \\
\hline $\mathrm{HCO}_{3}{ }^{-}$ & $\mathrm{mg} / 1$ & 4.2 & 11.8 & 7.24 & 7 & - \\
\hline $\mathrm{SO}_{4}{ }^{2-}$ & $\mathrm{mg} / 1$ & 0.2 & 0.6 & 0.39 & 0.4 & 500 \\
\hline $\mathrm{NO}_{3}{ }^{-}$ & $\mathrm{mg} / 1$ & 0.03 & 3.69 & 2.19 & 2.28 & 50 \\
\hline $\mathrm{Na}^{+}$ & $\mathrm{mg} / 1$ & 2.6 & 4.7 & 3.71 & 3.6 & 200 \\
\hline $\mathrm{K}^{+}$ & $\mathrm{mg} / 1$ & 0.29 & 0.51 & 0.39 & 0.41 & - \\
\hline $\mathrm{Mg}{ }^{2+}$ & $\mathrm{mg} / 1$ & 0.14 & 0.65 & 0.3 & 0.27 & 0.4 \\
\hline $\mathrm{Ca}^{2+}$ & $\mathrm{mg} / 1$ & 0.51 & 1.44 & 0.81 & 0.75 & - \\
\hline $\mathrm{Cr}$ & $\mu \mathrm{g} / 1$ & 0.09 & 0.5 & 0.2 & 0.2 & 5 \\
\hline $\mathrm{Cu}$ & $\mu \mathrm{g} / 1$ & 0.2 & 2.2 & 0.48 & 0.27 & 200 \\
\hline $\mathrm{Rb}$ & $\mu \mathrm{g} / 1$ & 1.4 & 2.4 & 1.83 & 1.85 & - \\
\hline $\mathrm{Sr}$ & $\mu \mathrm{g} / 1$ & 2.4 & 4.85 & 3.16 & 3 & - \\
\hline $\mathrm{Pb}$ & $\mu \mathrm{g} / 1$ & 0.01 & 0.3 & 0.08 & 0.06 & 1 \\
\hline
\end{tabular}


To evaluate whether or not these waters could be used for drinking purposes, the chemical data was compared with the maximum permissible concentrations indicated in the World Health Organization guidelines [7] and reported in Table 1. Nearly all the analyzed samples fall within the range of drinkable waters, with the exception of a few whose $\mathrm{Mg}^{2+}$ (maximum value $0.65 \mathrm{mg} / \mathrm{l}$ ) contents were high. This excess can probably be referred to natural water-rock interaction processes.

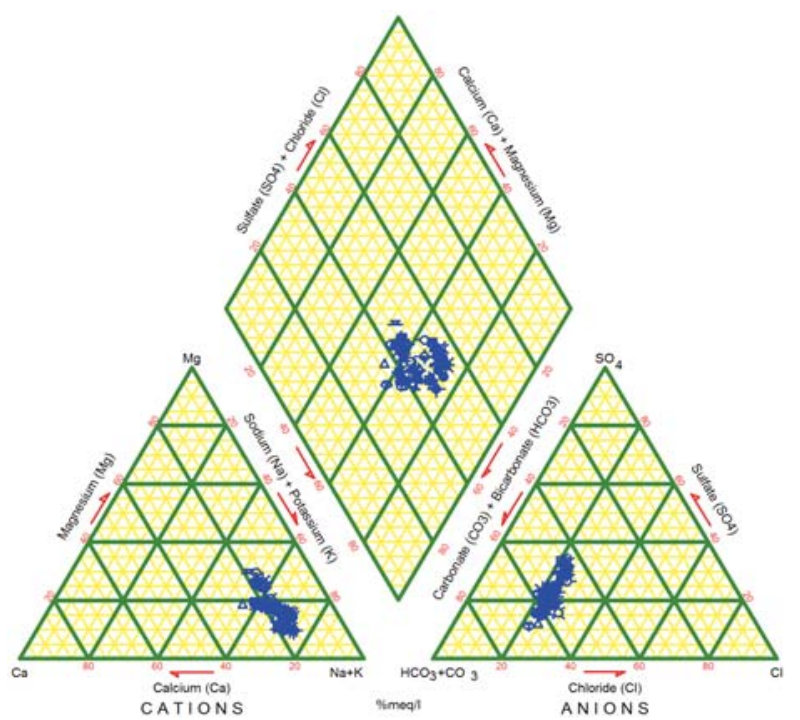

Fig. 3 Piper trilinear diagram of water chemistry in Castelo Novo

From the interpretation of the chemical analyses made during this study, it can be noticed a relative temporal stability of the chemical characteristics of the different elements, thus allowing to provide a hydrogeochemical characterization and the definition of the base contents of these aquifers, any time of the year, without any data loss.

\section{Multivariate analysis}

One of the fundamental problems associated with any environmental diagnosis, is linked to the great amount of data one has to deal with. The large dimension of the tables, either because of the number of samples or variables, makes impracticable any 'manual' research of relations, being necessary the asset to mathematical techniques of data processing that can synthesize, with a minimum of data loss, the most relevant information. Such techniques belong to the family of the Factorial Methods of Data Analysis, where the analysis in principal elements is included.

The objective of the factorial analysis is to study the chemism of the aquifer and explain the diversification of data through a small number of factors [8]. The practical application of the methods of factorial analysis to hydrogeochemical studies of aquifers has an undeniable success $[9,10,11,12,13]$.

In order to clarify the relations between the variables in the samples of groundwater, it was characterized each pattern created from the binomial samples versus variables $(50 \times 14$, being 50 the number of samples and 14 the number of variables).

The tables 2 and 3 present, respectively, the co-ordinates of the variables in the factorial axes, the real value and the percentage of the variance explained for each one of the factorial axes, resulting of the Analysis in Principal Elements of the 50 samples of groundwater.

Co-ordinates of the variables in the factorial axes

Table 2

\begin{tabular}{|c|c|c|c|c|}
\hline Variables & Factor 1 & Factor 2 & Factor 3 & Factor 4 \\
\hline $\mathrm{SiO}_{2}{ }^{2+}$ & 0,90 & -0.04 & -0.11 & -0.28 \\
\hline $\mathrm{Cl}^{-}$ & 0,55 & 0.47 & -0.42 & 0.08 \\
\hline $\mathrm{HCO}_{3}{ }^{-}$ & 0.93 & -0.15 & 0.23 & -0.12 \\
\hline $\mathrm{SO}_{4}{ }^{2-}$ & -0.62 & -0.01 & -0.33 & -0.05 \\
\hline $\mathrm{NO}_{3}{ }^{-}$ & 0.04 & 0.30 & -0.34 & 0.85 \\
\hline $\mathrm{Na}^{+}$ & 0.89 & -0.01 & -0.26 & -0.13 \\
\hline $\mathrm{K}^{+}$ & 0.45 & 0.13 & -0.73 & -0.23 \\
\hline $\mathrm{Mg}^{2+}$ & 0.50 & -0.15 & 0.79 & 0.16 \\
\hline $\mathrm{Ca}^{2+}$ & 0.92 & -0.01 & 0.13 & 0.21 \\
\hline $\mathrm{Cr}$ & 0.03 & -0.77 & -0.12 & -0.21 \\
\hline $\mathrm{Cu}$ & -0.02 & -0.83 & -0.27 & 0.31 \\
\hline $\mathrm{Rb}$ & 0.87 & -0.06 & -0.25 & -0.03 \\
\hline $\mathrm{Sr}$ & 0.86 & -0.06 & 0.20 & 0.34 \\
\hline $\mathrm{Pb}$ & -0.04 & -0.88 & -0.24 & 0.17 \\
\hline
\end{tabular}

Results of the Analysis in Principal Elements

Table 3

\begin{tabular}{|c|c|c|c|}
\hline Factor & Value Equity & Variance $\%$ & Total variance $\%$ \\
\hline 1 & 5.97 & 42.61 & 42.61 \\
\hline 2 & 2.43 & 17.33 & 59.94 \\
\hline 3 & 1.96 & 14.00 & 73.94 \\
\hline 4 & 1.25 & 8.90 & 82.84 \\
\hline
\end{tabular}

In a first analysis one can notice that the first 4 factors explain $82.84 \%$ of the total variance. The application of this method also allowed the reduction of the 'dimensionality' of the problem (14 original variables) only to 4 'potential' variables.

In Fig. $4 a$ ) and $4 b$ ) is presented the projection of the different variables in the first and second factorial plans defined, respectively, by the factors 1 and 2 and by the factors 1 and 3 . This visualization of the projections of the variables in the plan allows distinguishing the closeness and conflicts existing within them. The first factorial plan constituted by the factors 1 and 2 include $59.94 \%$ of the information contained in the pattern of correlation.

Factor 1 explains $42,61 \%$ of the total variance and includes the variables $\mathrm{SiO}_{2}{ }^{2+}, \mathrm{HCO}_{3}{ }^{-}, \mathrm{Na}^{+}, \mathrm{Ca}^{2+}, \mathrm{Rb}, \mathrm{Sr}, \mathrm{Cl}^{-}, \mathrm{SO}_{4}{ }^{2-}$ e $\mathrm{Mg}^{2+}$.

The association $\left(\mathrm{SiO}_{2}{ }^{2+}, \mathrm{HCO}_{3}{ }^{-}, \mathrm{Na}^{+}, \mathrm{Ca}^{2+}, \mathrm{Rb}, \mathrm{Sr}\right)$ is tightly correlated with factor 1 . This association characterizes the 

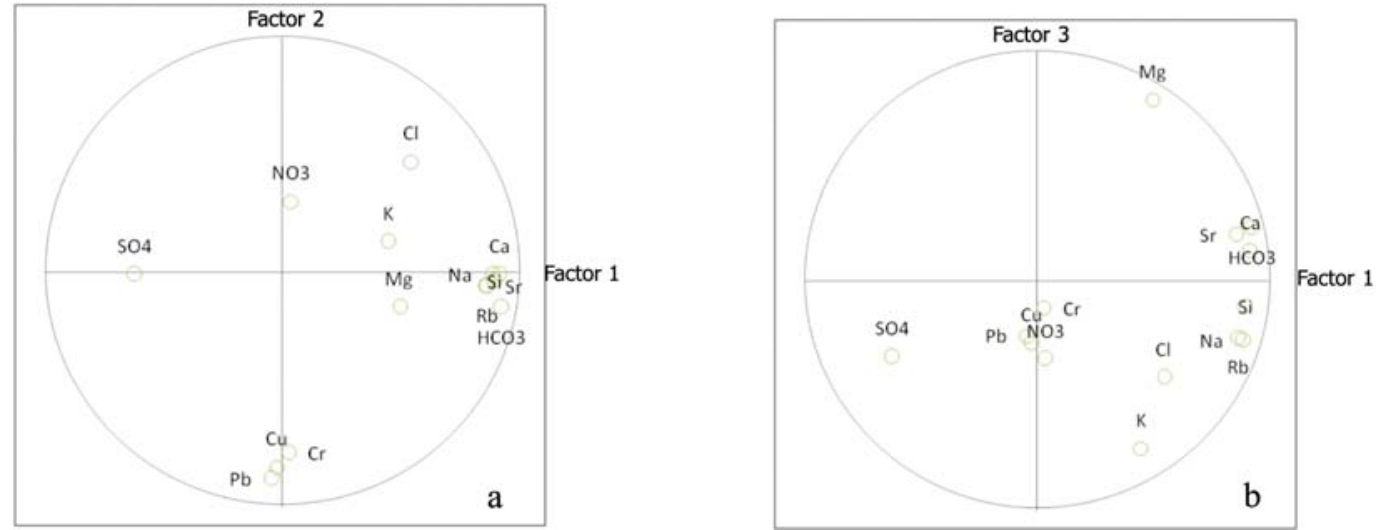

Fig. 4 a) Projection of the variables in the 1st factorial plan; b) Projection of the variables in the 2nd factorial plan

chemical composition of the water, whose origin may be found in the geology of the region, namely in the interaction water/rock. This association demonstrates the process of decomposition of the rock. The silicate minerals present in the granite are the main source of silica in the groundwater. The alteration of the granite is the main source of the presence of the ion $\mathrm{HCO}_{3}{ }^{-}$. The infiltration of the superficial waters containing $\mathrm{CO}_{2}$ attacks aggressively the aluminum silicate minerals, such as the micas and the feldspar present, releasing cations like the $\mathrm{Ca}^{2+}$ e o $\mathrm{Mg}^{2+}$ to the water and creating clay minerals. The consequences of this unsuitable dissolution are verified in an increase of the $\mathrm{pH}$ and the concentration of $\mathrm{HCO}_{3}{ }^{-}$in the groundwater [14]. The presence of sodium and calcium is due to the inconsequent dissolution of the plagioclases [15]. The ions $\mathrm{Cl}^{-}$e $\mathrm{Mg}^{2+}$ present a moderate correlation with factor 1 and the ion $\mathrm{SO}_{4}{ }^{2-}$ is correlated with the factor 1 of negative value, thus reflecting the hydrochemical classification obtained by the Piper diagram. The factor 1 shows clearly the interaction water/rock.

Factor 2 explains $17,33 \%$ of the total variance and includes the variables $\mathrm{Cr}, \mathrm{Cu}$ e $\mathrm{Pb}$.

The association $(\mathrm{Cr}, \mathrm{Cu}, \mathrm{Pb})$ is tightly correlated with the factor 2. This factor may show the process of percolation of the soil. The hard metals in the soil can be present in primary and secondary minerals, precipitate, absorbed, in the soil solution or in microorganisms, plants and animals.

Factor 3 explains $14,00 \%$ of the total variance and includes the variables $\mathrm{K}^{+}$e $\mathrm{Mg}^{2+}$.

The factor 3 explains the ion $\mathrm{K}^{+}$in opposition to the ion $\mathrm{Mg}^{2+}$. The presence of the $\mathrm{K}^{+}$can be due to the dissolution of the muscovites and the orthoclase present in the granite. The enormous resistance of the $\mathrm{K}^{+}$to the alteration and its solidification in the clay minerals formed by the processes of alteration [16] may explain this factor.

Factor 4 explains $8,90 \%$ of the total variance and includes the variable $\mathrm{NO}_{3}{ }^{-}$.

The ion $\mathrm{NO}_{3}{ }^{-}$is tightly correlated with the factor 4 . This factor characterizes the pollutant component of the water.

\section{Conclusion}

About the water quality in the granitic massif of the Gardunha mountain, namely in the area northeast area, it is important to refer to the fact that, through the physical and chemical analyses made in selected springs, at first sight very representative, all the waters are of sodium-bicarbonate type, being waters of very low mineralization, with TDS values equal or inferior to $42.3 \mathrm{mg} / \mathrm{l}$.

The lithological nature of the Gardunha mountain, in its granitic sector, is a great supply of aluminum silicates with alkali and alkali muddy cations that by hydrolysis allows the release of silica, calcium, sodium and potassium. These are easily soluble in a moderate acid environment, going to the surrounding water. From the chemical attack to the minerals of the rocks result insoluble residua formed by silica and by minerals from the clay group.

The order of the abundance of the major cations and anions is the following: $\mathrm{Na}^{+}>\mathrm{Ca}^{2+}>\mathrm{K}^{+}>\mathrm{Mg}^{2+}, \mathrm{HCO}_{3}{ }^{-}>\mathrm{Cl}^{-}>$ $>\mathrm{SO}_{4}{ }^{2-}>\mathrm{NO}_{3}{ }^{-}$.

The factorial analysis allowed studying the inter-correlation between the analyzed variables and establishing its distribution structure. 4 factors were obtained and they explain and identify the origin of the presence of ions in the underground water. The factor 1 reflects the signature of the interaction water/rock. The factor 2 materializes the percolation process of the hard materials of the soil. The factor 3 represents the dissolution process of the muscovites and the orthoclase present in the granite. The factor 4 has a pollutant feature materialized by the ion $\mathrm{NO}_{3}{ }^{-}$.

Acknowledgments The first author (Eric Mendes) would like to thank the Portuguese Foundation for Science and Technology and also Beira Vicente Lda. for funding the PhD grant (SFRH/BDE/ 33328/2008). Luís M. Ferreira Gomes and Eric Mendes would like to thank to CVRM-Centro de GeoSistemas for the facilities conceded and Paulo Carvalho also would like to thank to GEOBIOTEC for the facilities conceded. 


\section{References}

[1] RIBEIRO, L: Groundwaters in Portugal [in Portuguese]. In: Ribeiro L, Medeiros A, Abrunhosa M (eds) Engineering groundwater manual, Groundfos, Lisboa, 2004, p. 5-18

[2] MEDEIROS, A: Prospection, Investigation and Sizing of Groundwater Capitation [in Portuguese]. In:Ribeiro L, Medeiros A, Abrunhosa M (eds) Engineering groundwater manual, Groundfos, Lisboa, 2004, p. 5-18

[3] RIBEIRO, A., ANTUNES, M. T., FERrEIRA, M. P., ROCHA, R. B., SOARES, A. F., ZBYSZEWSKI, G., ALMEIDA, F. M., CARVAlHO, D., MONTEIRO, J. M.: Introduction in the General Geology of Portugal [in French]. Serv. Geol. Portugal, Lisboa, 1979, $114 \mathrm{p}$.

[4] RIBEIRO, A., ALMEIDA, F. M.: Low Enthalpy Geothermal Resources in Mainland Portugal [in Portuguese]. Geonovas, Rev. Assoc. Port. Geologos, Lisboa, vol. 1, n² 2, (1981), p. 60-70.

[5] INAG: National Institut of Water [in Portuguese], Sistema Nacional de Informacao de Recursos Hídricos, http://www.snirh.inag.pt/ Accessed Jan 2009

[6] LENCASTRE, A., FRANCO, F. M.: Hydrology Lessons [in Portuguese], Universidade Nova de Lisboa, Faculdade de Ciencias e Tecnologia, Monte da Caparica, 1984, $451 \mathrm{p}$.

[7] WHO: Guidelines for Drinking-water Quality, vol 1: Recommendations, 3rd edn. WHO, Geneva, 2004, ISBN 92-4-154696-4.

[8] RUIZ, F., GOMIS, V., BLASCO, P.: Application of Factor Analysis to the Hydrogeochemical Study of a Coastal Aquifer. J. of Hydrology 119:169-177, 1990, ISSN 0022-1694.

[9] LAWRENCE, W., UPCHURCH, S. B.: Identification of Geochemical Patterns in Groundwater by Numerical Analysis. In: Saleem ZA (ed) Advances in groundwater hydrology. American Water Resources Association, USA pp 199-214, 1976

[10] USUNOFF, E. J., GUZMAN, A. G.: Multivariate aAnalysis in Hydrochemistry. An Example of use of Fand Correspondence Analysis. Groundwater Journal 27:27-34, 1989, ISSN 1745-6584

[11] JAYAKUMAR, R., SIRAZ, L.: Factor Analysis in Hydrogeochemistry of Coastal Aquifers- a Preliminary study. Environmental Geology 31:174-177, 1997, ISSN 1432-0495

[12] CHAN-HO, J.: Mineral-water Interaction and Hydrogeochemistry in the Sankwang Mine Area, Korea. Geochemistry Journal 35:112, 2001

[13] YAMMANI, S. R., REDDY, T. V. K., REDDY, M. R. K.: Identification of Influencing Factors for Groundwater Quality Variation Using Multivariate Analysis. Environmental Geology 55:9-16, 2008, ISSN 1432-0495

[14] FREEZE, R. A., CHERRY, J. A.: Groundwater. Prentice-Hall : New Jersey, 1979, ISBN 0-13-365312-9

[15] SAETHER, O. M., CARITAT, P.: Geochemical Processes Weathering and Groundwater Recharge in Catchments. A.A. Balkema, Rotterdam, 1997

[16] GOLDICH, S. S.: A Study in Rock Weathering. The Journal of Geology 46:17, 1938, ISSN 0022-1376. 